\title{
Effects of artificial defoliation on growth, reproduction and leaf chemistry of the mangrove Kandelia candel
}

\author{
Y. F. Tong, S. Y. Lee ${ }^{1}$ and B. Morton \\ The Swire Institute of Marine Science and Department of Ecology and Biodiversity, The University of Hong Kong, Cape d'Aguilar, Shek O, \\ Hong Kong \\ (Accepted 27 July 2002)
}

\begin{abstract}
The effects of defoliation on leaf and propagule production, and leaf chemistry of the mangrove Kandelia candel (L.) Druce were evaluated in a manipulative experiment in Hong Kong. Artificial defoliation of leaf lamina at $50 \%$ of the length of midrib resulted in significant reduction in leaf, twig and propagule production, and size of the latter. Through the negative effects on propagule number and size, severe herbivory may influence fitness of the mangrove, and, thus, community structure. In contrast, no apparent adverse effects on growth and production were observable at $25 \%$ defoliation. Defoliation also significantly affected leaf chemistry of the trees, particularly those suffering $50 \%$ defoliation. Concentrations of soluble tannins and carbohydrates in leaves were significantly lower at $50 \%$ defoliation compared with the control. Total nitrogen also decreased significantly with increased per cent defoliation. Plants surviving in stressful habitats, such as mangroves, are probably more affected by loss of leaf biomass than those surviving in favourable environments.
\end{abstract}

Key Words: artificial defoliation, herbivory, Kandelia candel, leaf chemistry, mangrove, propagule production

\section{INTRODUCTION}

Herbivory can alter plant fitness by exerting effects on growth and reproduction (Crawley 1989, Kulman 1971, Obeso 1993). Data that substantiate these findings mainly come from either artificial defoliation or herbivore exclusion experiments. Mostly, the effects are negative for the plant (Anderson \& Lee 1995, Ang et al. 1994, Heichel \& Turner 1984, Lowman \& Heatwole 1987, Rockwood 1973, Stone \& Bacon 1995) but, in some cases, they can recover from the damage without any change in growth and reproduction (Lim \& Turner 1996, Lubbers \& Lechowicz 1989). There may even be overcompensation for the lost biomass (Hjalten et al. 1994, McNaughton 1986). These findings suggest that the effects of herbivory on plant growth and reproduction are subtle and deserve further investigation. Changes in plant growth and reproduction following herbivore attack have significant implications for the competitive fitness of plants in natural communities. Studies on insect-plant interactions have suggested that alterations in plant competitive relationships through selective herbivory can accelerate changes in community structure and development (Crawley 1989,

\footnotetext{
${ }^{1}$ Corresponding author: School of Environmental and Applied Sciences, Griffith University Gold Coast, PMB 50, GCMC, Q1d 9726, Australia. Email: joe.lee@mailbox.gu.edu.au
}

Schowalter et al. 1981, 1986; Seastedt \& Crossley 1984, Springett 1978, Weis \& Berenbaum 1989).

Although several incidences of high levels of herbivory in mangroves have been reported in recent decades (Anderson \& Lee 1995, Murphy 1990, Pikakarnchana 1981, Whitten \& Damanik 1986), assessments of the effects of herbivory on growth and reproduction remain scarce. Anderson \& Lee (1995) reported that regular, severe, defoliation of the mangrove Avicennia marina by the larvae of Nephopterix syntaractis (Lepidoptera: Pyralidae) in Hong Kong could significantly lower reproductive output. Ozaki et al. (1999) documented that attack by the scale insect Aulacaspis marina on Rhizophora mucronata saplings could result in mortality 82-159 d after infestation. However, these studies did not assess the effects of herbivory on mangrove growth (e.g. leaf production). Mangroves live in an environment that is stressful to higher plants. There is, therefore, a strong pressure to conserve resources, and the response of mangroves to severe herbivory damage would have significant implications for survival in this energy-demanding habitat.

Physical damage to leaves by insects has been shown to affect plant species adversely (Edwards \& Wratten 1986, Edwards et al. 1986, Gibberd et al. 1985, Haukioja \& Niemela 1979, Silkstone 1987, Wratten et al. 1984). There is increasing evidence that effects induced by 
herbivore attack can be attributed mainly to changes in leaf chemistry, including decreases in nutrient levels and increases in levels of secondary chemicals (Edwards \& Wratten 1986, Feeny 1970, Schultz \& Baldwin 1982, Tuomi et al. 1988, Webb 1980, Wold \& Marquis 1987). Insect-induced changes in plant chemistry have received the particular attention of scientists not only because they are regarded as a process leading to co-evolution (Ehrlich \& Raven 1964) but they may also be mechanisms by which insects affect ecosystem nutrient cycling (Choudhury 1988).

The aim of this study was to investigate the effects of different levels of herbivory loss on growth, reproductive output and leaf chemistry of the mangrove Kandelia candel by means of an artificial defoliation experiment. We hypothesized that severe defoliation would have greater effects on growth, leaf chemistry and reproduction than moderate defoliation in $K$. candel. Although this method is essentially different from natural herbivory as interactions through saliva and frass production by the herbivore are absent (Agrawal 1998, Baldwin 1990, Stowe et al. 2000), it is comparatively less time consuming and allows better control of treatment levels. The extent of damage can be controlled easily, and kept constant across replicates.

\section{MATERIALS AND METHODS}

\section{Effects of artificial defoliation on Kandelia candel}

The defoliation experiment was undertaken in the Kandelia candel mangal at Ting Kok, north-east Hong Kong $\left(22^{\circ} 28^{\prime} \mathrm{N}, 114^{\circ} 13^{\prime} \mathrm{E}\right)$. Nine trees of similar size were selected (girth: $25-30 \mathrm{~cm}$, height: $1.6-1.8 \mathrm{~m}$ ) in order to minimize age and other variations among them. Three trees per group were randomly assigned to one of the following treatments: control and one of two levels of artificial defoliation, i.e. $25 \%$ (the leaf lamina removed for the distal $1 / 4$ of the long leaf axis) and $50 \%$ (1/2 of the long axis of each leaf removed). Levels of herbivory on $K$. candel are usually low $(<10 \%$; Lee 1991) and the artificial damage levels were targeted at simulating massive defoliation events. Defoliation has been recorded for a sympatric mangrove species Avicennia marina (Anderson \& Lee 1995) by a moth Nephopterix sintaractis, making this mangrove species unsuitable for the present experiment (because of the variable background herbivory levels). Defoliation was started in early June, at the period of flowering, and was finished within a period of $3 \mathrm{wk}$.

Effects of defoliation treatment on the growth of Kandelia candel were assessed by comparing the production rates of leaves and twigs, and the percentage increase in trunk diameter (dbh) of the control and experimental trees. Assessment of the production rates of leaves and twigs were conducted by using the same methods for assessment of the turnover factors of the leaf and twig as described in Lee (1991). Ten shoots per tree were tagged randomly in April 1994. Changes in these shoots $1 \mathrm{y}$ after treatment were recorded. The production rates/turnover factors were expressed as the ratio of leaves/twigs after $1 \mathrm{y}$ to the initial value, using trees as replicates. Comparisons of the production rates of the control and experimental trees before treatment were not possible due to time constraints with this experiment. Tong (1998) has, however, shown that the turnover factors for leaves and twigs of $K$. candel at Ting Kok were both equal to 2.6×. It was therefore assumed that the production rates of the leaves and twigs of the control and experiment trees before the treatment were also equal to $2.6 \times$. Percentage increases in trunk diameter of the trees were determined by measuring them at different points around the trunk at breast height $(1.3 \mathrm{~m}, \mathrm{dbh})$ to the nearest $0.1 \mathrm{~cm}$, before and $1 \mathrm{y}$ after treatment.

To measure the effect of defoliation on the reproductive output of Kandelia candel, propagule production of the control and experimental trees were compared. Propagules of $K$. candel are cylindrical, and detach from the mother tree when mature after a 'gestation period' of about 8 mo and growth to $<25 \mathrm{~cm}$. All the propagules detached from the control and experimental trees in 1994 and 1995, i.e. before and after treatment, were collected by litter traps. The litter traps used in this experiment were the enclosure type in which the entire tree was surrounded. Each enclosure was constructed by placing four $4-\mathrm{cm} \times 4-\mathrm{cm}$ wooden stakes in the substratum, forming a polygon around the tree. Plastic screenings of mesh size $1 \mathrm{~mm}^{2}$ were wrapped around the stakes enclosing the tree and around its trunk below the lowest branches. This setting formed an envelope around the experimental tree and caught only those propagules from it. The propagules inside the traps were collected during biweekly visits over the experimental period. These were washed and oven dried at $80{ }^{\circ} \mathrm{C}$ for $2 \mathrm{~d}$. The numbers and mean dry weights of the propagules collected from each tree in 1994 and 1995 were recorded.

The effects of artificial defoliation on leaf chemistry were monitored. Pre-treatment foliage sampling was undertaken at the beginning of June. Triplicate samples of ten young leaves were removed randomly from each tree. Leaf samples were then oven dried at $40{ }^{\circ} \mathrm{C}$ for $24 \mathrm{~h}$ and analysed for total soluble tannins, total soluble carbohydrates and total nitrogen using methods described in Allen (1989). After treatment, leaf samples were collected monthly from July 1994 to February 1995 in the same way as described above and then subjected to chemical analysis.

\section{Statistical analyses}

One-way ANOVAs were used to compare the production rates of leaves and twigs of the three treatment groups 
after treatment. In cases where significant differences between treatment groups were detected, Student Newman-Keuls multiple tests (SNK) were used to identify them (at $\alpha=0.05$ ). Increases in trunk diameter of the three treatment groups were compared by analysis of covariance (ANCOVA) with the initial dbh of the trees as the covariate.

The difference in the number and mean dry weight of propagules produced by the three groups before and after treatment were compared by two-way ANOVAs with time and treatment as the factors. Thereafter, SNK multiple tests were used to identify the differences, if any.

All percentage data on leaf chemical contents were arcsine transformed prior to analysis in order to conform to the assumptions of normality and homoscedasticity for the ANOVA. The chemical contents of the three groups of trees before treatment were compared statistically using one-way ANOVA. After defoliation, the chemical contents of the leaves of the control and experimental trees were compared by repeated-measure ANOVAs, with time (month) as the repeated measure. Sphericity was accounted for in all repeated-measure ANOVAs by modifying degrees of freedom using the Geisser-Greenhouse approximation (Stevens 1999). Significant differences between treatments were identified using Bonferroni $\mathrm{t}$-tests as the post hoc procedures. Statistical analyses were performed using SPSS for Windows, SPSS Inc.

\section{RESULTS}

\section{Leaf and propagule production}

The production rates of leaves and twigs of the control trees recorded in 1995 were comparable with those recorded at the same site. This finding implies that there were no remarkable changes in the production rates of leaves and twigs of the control trees $1 \mathrm{y}$ after the commencment of the experiment. Significant differences in the production rates of leaves and twigs among groups were evident $1 \mathrm{y}$ after defoliation (Table 1). Trees subjected to $50 \%$ defoliation showed a significant reduction in the production rates of leaves and twigs as compared with the control (SNK multiple test: $\mathrm{p}=2, \mathrm{q}=6, \mathrm{P}<$ $0.05, \mathrm{p}=3, \mathrm{q}=5.1, \mathrm{P}<0.05$, respectively) and the $25 \%$ defoliated trees $(\mathrm{p}=3, \mathrm{q}=16, \mathrm{P}<0.05, \mathrm{p}=2, \mathrm{q}=4.5$, $\mathrm{P}<0.05$, respectively). The leaf production rate of the $25 \%$ defoliated trees was significantly higher than that of the control $(\mathrm{p}=2, \mathrm{q}=10, \mathrm{P}<0.05)$ but no significant difference in twig production rate was detected among these two treatment groups $(\mathrm{p}=2, \mathrm{q}=0.59, \mathrm{P}>0.05)$. No significant differences were recorded in the percentage increases in trunk diameters among the treatment groups.

Results of the two-way ANOVAs show that the number and mean dry weight of the propagules produced by Kandelia candel were influenced by the degree of defoliation (Table 2). The higher the level of defoliation experienced by the trees, the fewer the number of propagules they produced and the lower their mean dry weight (Figure 1). Significant differences in the number of propagules were detected between the control and the $50 \%$ defoliated trees (SNK multiple test: $\mathrm{p}=3, \mathrm{q}=7.11, \mathrm{P}<0.05)$ and between the $25 \%$ and $50 \%$ defoliated trees (SNK multiple test: $\mathrm{p}=$ $2, q=4.86, P<0.05)$. Significant difference in the mean dry weight of the propagules was found between the control and the $50 \%$ defoliated trees only (SNK multiple test: $\mathrm{p}=3, \mathrm{q}=4.38, \mathrm{P}<0.05)$. In addition to the defoliation treatment, time and the interaction effects of these two factors could significantly influence the number and average dry weight of the propagules produced.

The pretreatment levels, i.e. levels measured in June, of total nitrogen, total soluble carbohydrates and total soluble tannins did not differ between the three groups of trees (one-way ANOVA: $\mathrm{F}=0.065, \mathrm{P}=0.94, \mathrm{~F}=0.447$, $\mathrm{P}=0.66, \mathrm{~F}=0.321, \mathrm{P}=0.74$, respectively; Figure 2 ). Shortly after the defoliation treatment, i.e. in July, differ-

Table 2. Results of two-way ANOVAs on the effects of defoliation and time on the number and the mean dry weight of propagules produced by Kandelia candel.

\begin{tabular}{lccc}
\hline Source of variance & df & F & $P$ \\
\hline Number of propagules & & & \\
$\quad$ Treatment & 2 & 13.2 & $<0.001$ \\
Time & 1 & 68.3 & $<0.0001$ \\
$\quad$ Treatment $\times$ Time & 2 & 6.61 & 0.012 \\
Mean dry weight of propagules & & & \\
$\quad$ Treatment & 2 & 4.86 & 0.028 \\
$\quad$ Time & 1 & 9.01 & 0.011 \\
Treatment $\times$ Time & 2 & 4.17 & 0.030 \\
\hline
\end{tabular}

Table 1. The leaf and twig production rates and the percentage increase in trunk diameter of Kandelia candel that were subjected to three different levels of defoliation treatments. Production rates were expressed as the number of times of increase in the number of leaf or twig per shoot per year. Values are mean $\pm 1 \mathrm{SD}$.

\begin{tabular}{lccc}
\hline Treatment & \multicolumn{3}{c}{ Parameters } \\
\cline { 2 - 5 } & $\begin{array}{c}\text { Production rate of } \\
\text { leaf }\end{array}$ & $\begin{array}{c}\text { Production rate of } \\
\text { twig }\end{array}$ & $\begin{array}{c}\text { Increase in trunk } \\
\text { diameter }(\%)\end{array}$ \\
\hline Control & $2.4 \pm 0.1$ & $2.6 \pm 0.2$ & $3.1 \pm 1.5$ \\
$25 \%$ defoliation & $3.4 \pm 0.2$ & $2.5 \pm 0.1$ & $3.3 \pm 0.7$ \\
$50 \%$ defoliation & $1.8 \pm 0.2$ & $1.8 \pm 0.2$ & 7.78 \\
$\mathrm{~F}$ & 65.3 & 0.022 & 0.026 \\
$\mathrm{P}$ & $<0.0001$ & 0.97 & 1.0 \\
\hline
\end{tabular}



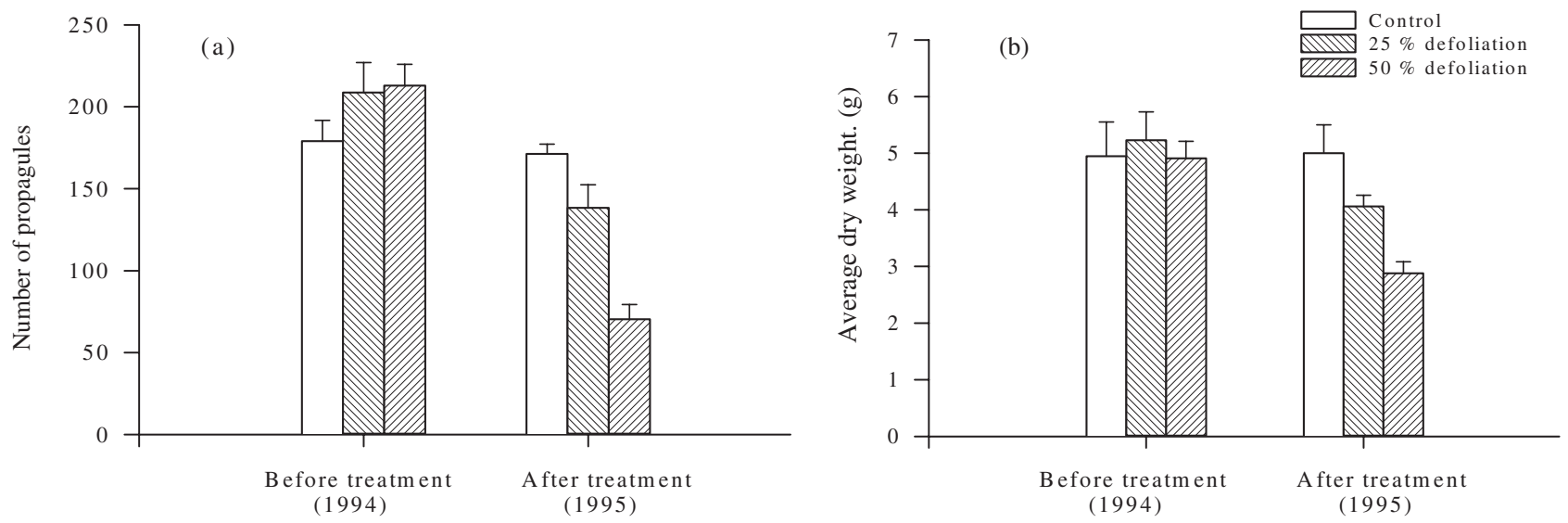

Figure 1. (a) Number and (b) average dry weight (g) of propagules collected from the control and defoliated trees before and after treatment. Values are mean $+1 \mathrm{SD}$.

ences in contents of total nitrogen, total soluble carbohydrates and total soluble tannins among the three treatment groups became obvious. Repeated-measure ANOVAs show that defoliation treatments had significant effects on the leaf chemical contents, as measured during the study period (nitrogen: $\mathrm{F}=32.2, \mathrm{P}=0.001$, carbohydrates: $\mathrm{F}=$ 7.19, $\mathrm{P}=0.026$, tannin: $\mathrm{F}=15.5, \mathrm{P}=0.004$, Table 3 ). Defoliation treatments $(25 \%$ or $50 \%$ ) caused reductions in the concentrations of all the measured leaf chemical parameters when compared with that of the control (Table 3 ). The higher the level of defoliation the trees experienced, the greater the decrease in concentrations of their leaf chemical contents. Differences in concentration of total soluble carbohydrates and total soluble tannins were, however, significant only between the control and the $50 \%$ defoliated trees (Bonferroni t-test: $\mathrm{t}=3.62, \mathrm{P}<0.05$, $\mathrm{t}=5.45, \mathrm{P}<0.05$, respectively) but not between the control and the $25 \%$ defoliated trees $(\mathrm{t}=0.82, \mathrm{P}>0.05, \mathrm{t}=$ $2.70, \mathrm{P}>0.05$, respectively) or the $25 \%$ and $50 \%$ defoliated trees $(\mathrm{t}=2.79, \mathrm{P}>0.05, \mathrm{t}=02.75, \mathrm{P}>0.05$, respectively). Foliage concentration of total nitrogen differed significantly between the control and the $25 \%$ defoliated trees and between the control and the $50 \%$ defoliated trees (Bonferroni t-test: $\mathrm{t}=7.89, \mathrm{P}<0.05, \mathrm{t}=$ 5.22, $\mathrm{P}<0.05$, respectively) but not between the two groups of defoliated trees $(\mathrm{t}=2.67, \mathrm{P}>0.05)$.

Significant effects of time on the total soluble carbohydrates and total soluble tannins of the treatment groups were shown even after the results had been adjusted by the Geisser-Greenhouse approximation $(F=13.1$, Adj. $\mathrm{P}=0.0001, \mathrm{~F}=28.0$, Adj. $\mathrm{P}=0.0001$, respectively) (Table $4 \mathrm{~b}$ and $\mathrm{c}$ ). There were, however, no clear patterns of change with time in these two parameters of the three treatment groups, as shown in Figures $2 \mathrm{~b}$ and $2 \mathrm{c}$. The interaction of treatment and time was significant for total soluble tannins $(\mathrm{F}=5.28$, Adj. $\mathrm{P}=0.002)$ but not for total soluble carbohydrates $(F=2.66$, Adj. $P=0.052)$. The effects of time and its interaction with treatment for total nitrogen were also not significant $(\mathrm{F}=2.50$, Adj. $\mathrm{P}=$ $0.123, \mathrm{~F}=1.70$, Adj. $\mathrm{P}=0.213$, respectively, Table $4 \mathrm{a}$ ).

\section{DISCUSSION}

Results of the present study demonstrated that defoliation could impact the growth of Kandelia candel differentially in accordance with the level of leaf area lost (Table 1). The treatment plants with $25 \%$ total leaf area removal did not differ significantly in the production of new twigs and growth in trunk diameter as compared with the control. The defoliation treatment, however, did significantly increase the production rate of new leaves by $41.7 \%$. Increase in leaf initiation is probably a compensatory response by $K$. candel to moderate levels of insect herbivory $(<25 \%)$ so as to alleviate the potential deleterious effects of tissue loss. By comparing the degree of damage of leaves in litter traps and on the canopy, Lee (1990) concluded that herbivory probably reduced leaf longevity of $K$. candel, a result that was supported by an artificial damage experiment (Lee 1991). Compensatory plant growth in response to herbivory has already been reported for a large variety of plants of different taxonomic origins and habits (Doak 1992, Escarre et al. 1996, Harrison \& Maron 1995, Lim \& Turner 1996, Marquis 1984, Oba 1994, Schierenbeck et al. 1994). In this study, the mechanisms involved in the compensatory response of $K$. candel are not known, although resource allocation is certainly altered as a result of defoliation. A plant's temporal variation in allocation can have important consequences for either the ultimate gain or loss of its resources and subsequently define its ecological role and distribution (Bazzaz et al. 1987). The adaptive response to reallocate more resources for leaf production can be beneficial to the mangroves in at least three ways. First, an increase in leaf production can speed up the replacement of lost tissues and ensure future photosynthetic production. Second, as leaves of $K$. candel are important in the process of salt 

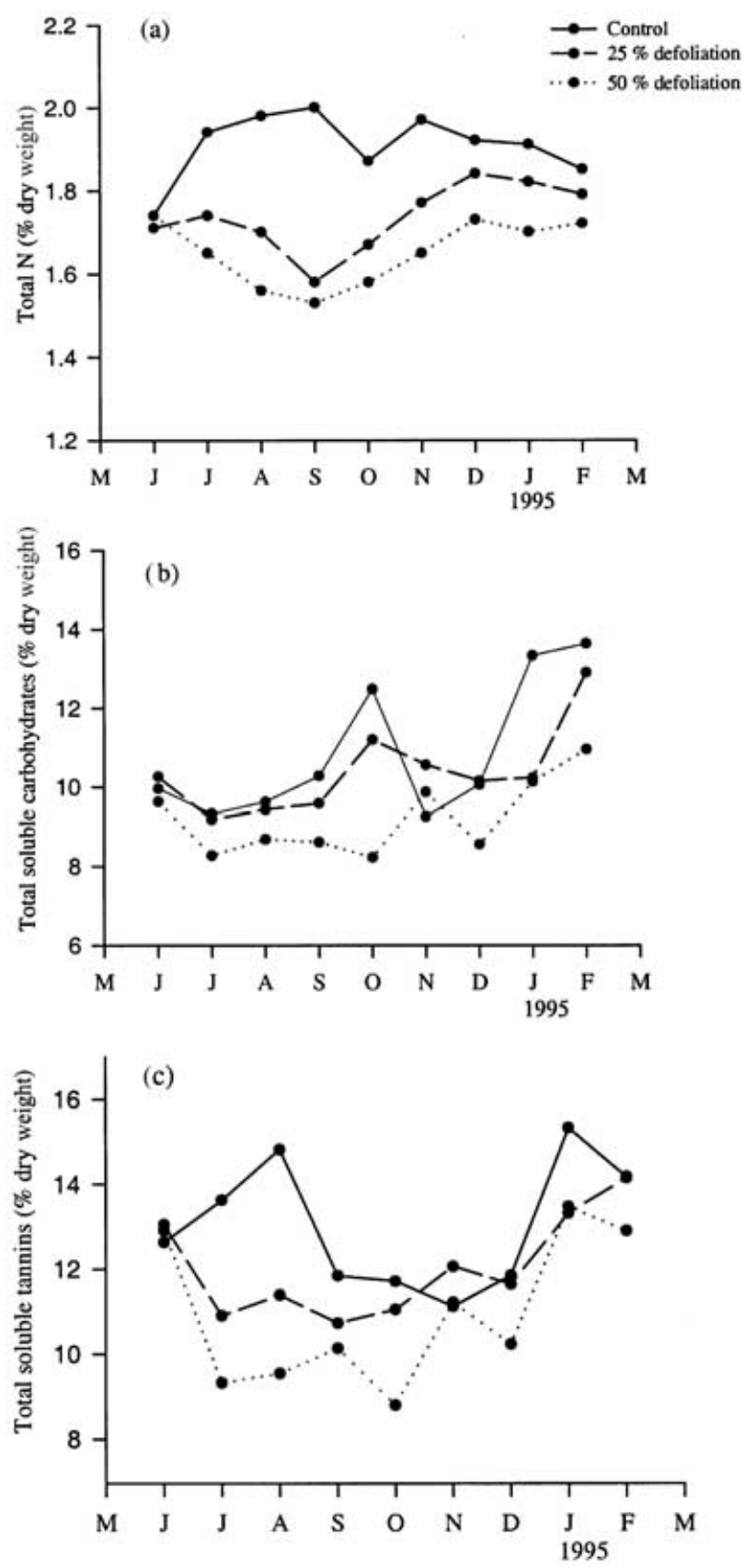

Figure 2. Variations in the mean concentration of (a) total nitrogen; (b) total soluble carbohydrates; (c) total soluble tannins in the leaves of Kandelia candel collected from defoliated and control trees. Error bars have been omitted for clarity.
Table 4. Results of repeated-measure analysis of variance on the percentage of (a) total nitrogen, (b) total soluble carbohydrates and (c) total soluble tannins in leaves of Kandelia candel from experimental and control trees.

\section{(a) Total nitrogen}

\begin{tabular}{|c|c|c|c|c|}
\hline \multirow[b]{2}{*}{ Source of variance } & \multirow[b]{2}{*}{ df } & \multicolumn{2}{|c|}{ Between subjects } & \\
\hline & & $\mathrm{F}$ & $\mathrm{P}$ & \\
\hline Treatment & 2 & 32.2 & 0.001 & \\
\hline \multirow{2}{*}{ Error } & 6 & \multirow{2}{*}{\multicolumn{2}{|c|}{ Within subject }} & \\
\hline & & & & \\
\hline Source of variance & df & $\mathrm{F}$ & $\mathrm{P}$ & $\begin{array}{l}\text { Adj. P } \\
\text { (G-G) }\end{array}$ \\
\hline Time & 7 & 2.50 & 0.031 & 0.123 \\
\hline Treatment $\times$ Time & 14 & 1.70 & 0.092 & 0.213 \\
\hline Error & 42 & & & \\
\hline
\end{tabular}

Greenhouse-Geisser $\varepsilon=0.289$

(b) Total soluble carbohydrates

\begin{tabular}{|c|c|c|c|c|}
\hline \multirow[b]{2}{*}{ Source of variance } & \multirow[b]{2}{*}{ df } & \multicolumn{2}{|c|}{ Between subjects } & \\
\hline & & $\mathrm{F}$ & $\mathrm{P}$ & \\
\hline Treatment & 2 & 7.19 & 0.026 & \\
\hline Error & 6 & \multicolumn{2}{|c|}{ Within subject } & \\
\hline Source of variance & df & $\mathrm{F}$ & $\mathrm{P}$ & $\begin{array}{r}\text { Adj. P } \\
\text { (G-G) }\end{array}$ \\
\hline Time & 7 & 13.1 & 0.0001 & 0.0001 \\
\hline Treatment $\times$ Time & 14 & 2.66 & 0.007 & 0.0520 \\
\hline Error & 42 & & & \\
\hline
\end{tabular}

(c) Total soluble tannins

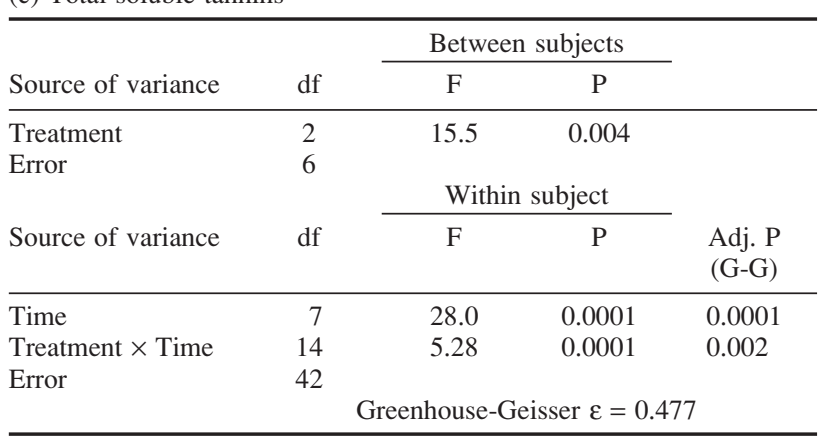

excretion, the rapid replacement of lost tissues is essential to ensure the adaptability of the mangroves to the saline habitat. Increases in leaf production may also lead to overcompensation and possibly increase the fitness of the affected plants.

The ability of plants to regrow has also been suggested

Table 3. Chemical concentrations in the leaves of Kandelia candel from the control and experimental trees after defoliation. Values are means of the data taken from July 1994 to February 1995 ( \pm 1 SE).

\begin{tabular}{lccc}
\hline $\begin{array}{l}\text { Chemical } \\
\text { concentration (\%) }\end{array}$ & \multicolumn{3}{c}{ Treatment } \\
\cline { 2 - 4 } & Control & 25\% defoliation & $50 \%$ defoliation \\
\hline Tannins & $13.1 \pm 0.6$ & $11.9 \pm 0.4$ & $10.7 \pm 0.6$ \\
Carbohydrates & $11.0 \pm 0.7$ & $10.4 \pm 0.4$ & $9.2 \pm 0.4$ \\
Nitrogen & $1.93 \pm 0.02$ & $1.74 \pm 0.03$ & $1.64 \pm 0.03$ \\
\hline
\end{tabular}


as an alternative defence strategy in the struggle against herbivores (van der Meijden et al. 1988). A plant's susceptibility and response to herbivory, however, is plastic and varies according to the biotic and abiotic conditions it experiences (Ang et al. 1994, Foggo 1996, Lim \& Turner 1996, Maschinski \& Whitham 1989, McKillup \& McKillup 1997, Trlica \& Rittenhouse 1993). In this study, the treatment plants subjected to $50 \%$ defoliation did not show any additional compensatory response to replace the lost tissues. Instead, leaf and twig production rates were significantly reduced by $25 \%$ and $30 \%$ respectively, as compared with the control (Table 1). The increment in trunk diameter of the $50 \%$ defoliated plants was lower in magnitude than that of the other treatment groups, although statistical analysis did not indicate a significant treatment effect. These findings suggest that the growth of Kandelia candel in Hong Kong can be hampered by a high level of herbivory, even a single attack. The fact that mangroves survive in habitats generally stressful to higher plants means that severe defoliation may have strong fitness implications for the trees. In cases of severe and repeated defoliation, as reported from other mangroves, e.g. Avicennia alba in Thailand (Pikakarnchana 1981), Excoecaria agallocha in Indonesia (Whitten \& Damanik 1986), Avicennia marina in Hong Kong (Anderson \& Lee 1995), there may well be loss of tree vigour and the mangroves may become more susceptible to other stresses such as increases in salinity and flooding (Grace \& Ford 1996).

The reproductive output of Kandelia candel was apparently impaired 1 y after defoliation (Figure 1, Table 2). The number of propagules produced by the defoliated trees decreased as the percentage of leaf area lost increased, indicating that reproductive output of $K$. candel may be dependent on leaf area. At a high level of defoliation, i.e. $50 \%$, the mean number of propagules produced by the defoliated trees was significantly different from that of the controls, by $\sim 60 \%$. Reduction in seed production after defoliation strongly suggests that there is a limitation in the availability of carbohydrates (Crawley 1983). Viviparous trees, such as $K$. candel, are expected to invest a large proportion of their photosynthate in seed production because of the long gestation period (c. $8 \mathrm{mo}$ in $K$. candel) and large propagule size. Mature propagules of $K$. candel have the same energy content $\left(18.3 \mathrm{~kJ} \mathrm{~g}^{-1}\right.$ dry weight; S. Y. Lee, unpubl. data) as other components of the mangrove litter but contribute to about $40 \%$ of total litter fall of the species (Lee 1989). After defoliation, competition for growth and reproduction resources may occur. To ensure survival and fitness and to regain a competitive status, the best strategy for recovery from defoliation is always to produce as nearly normal a photosynthetic machinery as possible (Hodkinson \& Hughes 1982). Resources allocated to reproduction will, therefore, be diminished. In a similar study, Anderson \& Lee (1995) showed that leaf regeneration of Avicennia marina after being attacked by the larvae of Nephopterix syntaractis (Lepidoptera: Pyralidae) was rapid, being achieved within 3 mo of defoliation, but reproduction was seriously impaired. They showed that reproduction only occurs in years in which defoliation is absent or less severe.

In addition to the suppression of propagule production, the mean size of the propagules on those plants that had experienced a high level of defoliation, i.e. $50 \%$, was significantly reduced (Figure $1 b$ ). Studies on the impact of insect herbivory on seed production are many but the effects on their mass are often neglected. Among the few studies which report upon this, it has been shown that a plant's seed mass can be increased, e.g. Erythroxylum havanense (Dominguez \& Dirzo 1994), Raphanus sativus (Agrawal 1998); decreased, e.g. Acacia farnesiana (Rockwood 1973), Vicia hirsuta (Brown et al. 1987) or remain unaffected, e.g. Vicia sativa (Brown et al. 1987) as a consequence of defoliation, indicating that effect varies with species. Although smaller propagules will still germinate, seedling establishment may be impaired, particularly in viviparous species, such as many mangroves. Lin \& Sternberg (1995) argued that seedlings of Rhizophora mangle from large propagules may have a greater chance of success in early establishment than those from smaller ones because of the former's better capability to grow and fix carbon dioxide. In addition to direct seed predation (Robertson 1991, Robertson et al. 1990, Smith et al. 1989), the present findings collectively suggest that species-specific insect herbivory, especially under a severe attack, may influence the community structure and development of mangroves through detrimental effects on the quantity and quality of propagule production.

The data in the present study provide evidence that herbivory damage on the mangrove Kandelia candel can lead to changes in leaf chemistry including the levels of nutrients and secondary chemicals. As changes in leaf chemistry after wounding have been shown to have adverse effect on insect performance in many plant species, there is a tacit assumption in plant-herbivore studies that deterioration in leaf quality upon herbivore attack may actually represent an active defence by plants against insect herbivores (Edwards \& Wratten 1986, Edwards et al. 1986, Rhoades 1979). Although nutrient concentrations in the regenerated foliage of Kandelia candel were shown to decrease after defoliation, the concentration of total soluble tannins, which is commonly regarded as an insectdeterrent, also decreased. As such, it seems that the idea of short-term active plant defensive responses induced by herbivory does not apply to $K$. candel. In fact, the lack of a plant response in the production of secondary chemicals to herbivore attack has also been recorded in other studies (Hjalten et al. 1994, Perebolotsky 1994), indicating that such a notion is still equivocal. Although the concentrations of tannin were lower in the foliage after defoliation, 
it is anticipated that the defoliated plants would be less attractive to subsequent attack by insect herbivores for two reasons. First, the insect herbivores may avoid feeding on the regenerated leaves of the treatment plants as the decrease in nutrients, especially nitrogen, may delay the herbivores' development and lead to increased mortality (Mattson 1980, Slansky 1993, Wratten et al. 1988). Low plant nutritive quality may probably have evolved in part as a defence against herbivores (Moran \& Hamilton 1980). Second, Tong (1998) has shown that there were differences in the contents of sodium, chloride, ash and crude fibre of $K$. candel leaves between two mangrove forests with different growth conditions. Such differences suggest that these chemicals may have potential deterrent effects on insect herbivores. Therefore, even though the foliage concentration of tannins was decreased after treatment, the defensive ability of the defoliated plants may not be weakened. The combined effect of poor nutrient level and the presence of deterrents may render regenerated leaves less palatable to insect herbivores. The changes in $K$. candel leaf chemistry after herbivory may protect the plant from chronic attack and hence allow regrowth.

Alternatively, the observed changes in leaf chemistry following defoliation could simply be a response dictated by the need to adjust the nutrient and energy allocation pattern of the trees to cope with the damage. It is also possible that the trees responded in producing defensive compounds that were not examined in this study. Chemical responses to herbivory in mangroves are poorly known. Feller (1995) recorded no effect of nutrient $(\mathrm{C}: \mathrm{N})$ ratio or concentrations of phenolics on the degree of herbivory on dwarf Rhizophora mangle trees, a result in contradiction with the earlier finding of Onuf et al. (1977). Farnsworth \& Ellison (1993), however, documented a significant effect of prior damage on subsequent herbivory level in $R$. mangle and Avicennia germinans in Belize, suggesting that the response of mangroves to herbivory is probably complex. More data on herbivory on mangroves in different nutrient and growth conditions are needed before an assessment of the general response pattern can be established.

Foliage concentrations of nitrogen and carbohydrates in Kandelia candel were shown to decrease after defoliation. As the defoliation level increased, both foliage concentrations of nitrogen and carbohydrates were significantly diminished. Such significant decreases in foliage nutrients in response to defoliation treatment suggest that the same process by insect herbivores is likely to have negative impact on the nutrient budget of $K$. candel. The effects of defoliation on the nutrient budget of plants have been investigated in other studies. For example, May \& Killingbeck (1995) reported that defoliation of Quercus ilicifolia by gypsy moth larvae (Lymantria dispar) caused a pronounced increase in the re-absorption of zinc and copper from senesced leaves and suggested that such changes represent a response to nutrient deficiencies induced by defoliation. Carbohydrate content in Pinus sylvestris foliage of different ages (Ericsson et al. 1980) and starch contents in all vegetative parts of the conifers Abies concolor and Pseudotsuga menziesii (Webb 1980) were shown to be reduced as a result of defoliation, which clearly reflects a shortage of these nutrients on a whole-tree basis. Such herbivory-induced effects are understandable because removal of biomass by herbivores always means a loss of nutrients from the plant. Effects of defoliation on plant nutrient budgets are more severe in evergreens than deciduous species. This is because the former, such as K. candel (Lin \& Lin 1990), usually store a much larger proportion of the total plant nutrient capital in their leaves than the latter group (Chapin 1980, Chapin et al. 1980, Mooney 1972), which leads to a rapid depletion in nutrient resources when herbivores consume the leaves. Rapid replenishment of nutrients by an increased nutrient uptake is unlikely as the mangrove ecosystem is usually nutrient limited, particularly with respect to nitrogen (Alongi et al. 1992, Clough et al. 1983, Onuf et al. 1977) and loss of photosynthetic tissues will diminish the production of photosynthate. Therefore, the nutrient loss upon herbivory, followed by a demand for additional nutrients for production of secondary leaves and repair, may adversely affect the mangrove nutrient budget and cause the plant to spend a long time recharging its nutrient resources. This herbivory-induced effect may limit the availability of nutrients to the various physiological processes of the plant.

In conclusion, as there are no apparent adverse impacts on the growth and reproductive output of the mangrove Kandelia candel with $25 \%$ defoliation, insect herbivory at nominal and medium levels is unlikely to affect the overall fitness of the plant. At either severe $(>50 \%)$ or repeated levels of defoliation, however, the overall fitness of the mangrove may be impaired through deleterious effects on growth and reproduction. Leaf quality in $K$. candel is generally depleted in response to herbivory and such changes become intensified as the level increases. These herbivore-induced effects may have significant implications for community dynamics.

\section{LITERATURE CITED}

AGRAWAL, A. A. 1998. Induced responses to herbivory and increased plant performance. Science 279:1201-1202.

ALLEN, S. E. 1989. Chemical analysis of ecological materials. Blackwell Scientific, Oxford. 368 pp.

ALONGI, D. M., BOTO, K. G. \& ROBERTSON, A. I. 1992. Nitrogen and phosphorus cycles. Pp. 251-292 in Robertson, A. I. \& Alongi, D. M. (eds). Coastal and estuarine studies: tropical mangrove ecosystems. American Geophysical Union, Washington.

ANDERSON, C. \& LEE, S. Y. 1995. Defoliation of the mangrove 
Avicennia marina in Hong Kong: cause and consequences. Biotropica 27:218-226

ANG, B. N., KOK, L. T., HALTZMAN, G. I. \& WOLF, D. D. 1994. Canada thistle (Cirsium arvense) response to simulated insect defoliation and plant competition. Weed Science 42:403-410.

BALDWIN, I. T. 1990. Herbivory simulations in ecological research. Trends in Ecology and Evolution 5:91-93.

BAZZAZ, F. A., CHIARIELlO, N. R., COLEY, P. D. \& PITELKA, L. R. 1987. Allocating resources to reproduction and defense. BioScience 37:58-67.

BROWN, V. K., GANGE, C. A., EVANS, I. M. \& STORR, A. L. 1987. The effect of insect herbivory on the growth and reproduction of two annual Vicia species at different stages in plant succession. Journal of Ecology 75:1173-1189.

CHAPIN, F. S. 1980. The mineral nutrition of wild plants. Annual Review of Ecology and Systematics 11:233-260.

CHAPIN, F. S., JOHNSON, D. A. \& MCKENDRICK, J. D. 1980. Seasonal movement of nutrients in plants of differing growth form in an Alaskan tundra ecosystem: implications for herbivory. Journal of Ecology 68:189-209.

CHOUDHURY, D. 1988. Herbivore induced changes in leaf-litter resource quality: a neglected aspect of herbivory in ecosystem nutrient dynamics. Oikos 51:389-393.

CLOUGH, B. F., BOTO, K. G. \& ATTIWILL, P. M. 1983. Mangroves and sewage: a re-evaluation. Pp. 151-161 in Teas, H. J. (ed.). Biology and ecology of mangroves. Dr W. Junk Publishers, The Hague.

CRAWLEY, M. J. 1983. Herbivory: the dynamics of animal-plant interactions. Blackwell Scientific, Oxford. 437 pp.

CRAWLEY, M. J. 1989. Insect herbivores and plant population dynamics. Annual Review of Entomology 34:531-564.

DOAK, D. F. 1992. Lifetime impacts of herbivory for a perennial plant. Ecology 73:2086-2099.

DOMINGUEZ, C. A. \& DIRZO, R. 1994. Effects of defoliation on Erythroxylum havanense, a tropical proleptic species. Ecology 75: 1896-1902.

EDWARDS, P. J. \& WRATTEN, S. D. 1986. Ecological significance of wound-induced changes in plant chemistry. Pp. 213-218 in Insectsplants: Proceedings of the sixth international symposium on insectplant relationships. Dr W. Junk Publishers, Dordrecht.

EDWARDS, P. J., WRATTEN, S. D. \& GREENWOOD, S. 1986. Palatability of British trees to insects: constitutive and induced defences. Oecologia 69:316-319.

EHRLICH, P. R. \& RAVEN, P. H. 1964. Butterflies and plants: a study of plant coevolution. Evolution 18:586-608.

ERICSSON, A., LARSSON, S. \& TENOW, O. 1980. Effects of early and late season defoliation on growth and carbohydrate dynamics in Scots pine. Journal of Applied Ecology 17:747-769.

ESCARRE, J., LEPART, J. \& SENTUC, J. J. 1996. Effects of simulated herbivory in Belizean mangal. Journal of Tropical Ecology 9:435453.

FEENY, P. 1970. Seasonal changes in oak leaf tannins and nutrients as a cause of spring feeding by winter moth caterpillars. Ecology 51:565581.

FELLER, I. C. 1995. Effects of nutrient enrichment on growth and herbi- vory of dwarf mangrove (Rhizophora mangle). Ecological Monographs 65:477-505.

FOGGO, A. 1996. Long- and short-term changes in plant growth following simulated herbivory: adaptive responses to damage? Ecological Entomology 21:198-202.

GIBBERD, R., EDWARDS, P. J. \& WRATTEN, S. D. 1985. Woundinduced changes in the acceptability of tree foliage to Lepidoptera: within-leaf effects. Oikos 51:43-47.

GRACE, J. B. \& FORD, M. A. 1996. The potential impact of herbivores on the susceptibility of the marsh plant Sagittaria lancifolia to saltwater intrusion in coastal wetlands. Estuaries 19:13-20.

HARRISON, S. \& MARON, J. L. 1995. Impacts of defoliation by tussock moths (Orgyia vetusta) on the growth and reproduction of bush lupine (Lupinus arboreus). Ecological Entomology 20:223-229.

HAUKIOJA, E. \& NIEMELA, P. 1979. Birch leaves as a resource for herbivores: seasonal occurrence of increased resistance in foliage after mechanical damage of adjacent leaves. Oecologia 39:151-159.

HEICHEL, G. H. \& TURNER, N. C. 1984. Branch growth and leaf numbers of red maple (Acer rubrum L.) and red oak (Quercus rubra L.): response to defoliation. Oecologia 62:1-6.

HJALTEN, J., DANELL, K. \& ERICSON, L. 1994. The impact of herbivory and competition on the phenolic concentration and palatability of juvenile birches. Oikos 71:416-422.

HODKINSON, I. E. \& HUGHES, M. K. 1982. Insect herbivory. Chapman and Hall, New York. 77 pp.

KULMAN, H. M. 1971. Effects of insect defoliation on growth and mortality of trees. Annual Review of Entomology 16:289-324.

LEE, S. Y. 1989. Litter production and turnover of the mangrove Kandelia candel (L.) Druce in a Hong Kong tidal shrimp pond. Estuarine, Coastal and Shelf Science 29:75-87.

LEE, S. Y. 1990. The intensity and consequences of herbivory on Kandelia candel (L.) Druce leaves at the Mai Po Marshes, Hong Kong. Pp. 717-725 in Morton, B. (ed.). The marine flora and fauna of Hong Kong and Southern China II. Hong Kong University Press, Hong Kong.

LEE, S. Y. 1991. Herbivory as an ecological process in a Kandelia candel (Rhizophoraceae) mangal in Hong Kong. Journal of Tropical Ecology 7:337-348.

LIM, W. H. L. \& TURNER, I. M. 1996. Resource availability and growth responses to defoliation in seedlings of three earlysuccessional, tropical, woody species. Ecological Research 11:321324.

LIN, G. \& STERNBERG, L. S. L. 1995. Variation in propagule mass and its effect on carbon assimilation and seedling growth of red mangrove (Rhizophora mangle) in Florida, U. S. A. Journal of Tropical Ecology 11:109-119.

LIN, P. \& LIN, G. 1990. Studies on the mangrove ecosystem of Jiulong River Estuary in China II. Accumulation and biological cycle of nitrogen and phosphorus elements in Kandelia candel community. Pp. 125-135 in Lin, P. (ed.). Mangrove research papers I (1980-1989). Xiamen University Press, China.

LOWMAN, M. D. \& HEATWOLE, H. 1987. The impact of defoliating insects on the growth of eucalypt saplings. Australian Journal of Ecology 12:175-181.

LUBBERS, A. E. \& LECHOWICZ, M. J. 1989. Effects of leaf removal 
on reproduction vs. belowground storage in Trillium grandiflorum. Ecology 70:85-96.

MARQUIS, R. J. 1984. Leaf herbivores decrease fitness of a tropical plant. Science 226:537-539.

MASCHINSKI, J. \& WHITHAM, T. G. 1989. The continuum of plant responses to herbivory: the influence of plant association, nutrient availability and timing. American Naturalist 134:1-19.

MATTSON, W. J. 1980. Herbivory in relation to plant nitrogen content. Annual Review of Ecology and Systematics 11:119-161.

MAY, J. D. \& KILLINGBECK, K. T. 1995. Effects of herbivoreinduced nutrient stress on correlates of fitness and on nutrient resorption in scrub oak (Quercus ilicifolia). Canadian Journal of Forest Research 25:1858-1864.

MCKILLUP, S. C. \& MCKILLUP, R. V. 1997. An outbreak of the moth Achaea serva (Fabr.) on the mangrove Excoecaria agallocha. Pan-Pacific Entomologist 73:184-185.

MCNAUGHTON, S. J. 1986. On plants and herbivores. American Naturalist 128:765-770.

MOONEY, H. A. 1972. The carbon balance of plants. Annual Review of Ecology and Systematics 3:315-346.

MORAN, N. \& HAMILTON, W. D. 1980. Low nutritive quality as defense against herbivores. Journal of Theoretical Biology 86:247254.

MURPHY, D. H. 1990. The natural history of insect herbivory on mangrove trees in and near Singapore. Raffles Bulletin of Zoology 38:119204

OBA, G. 1994. Responses of Indigofera spinosa to simulated herbivory in a semidesert of North-West Kenya. Acta Oecologica 15:105-117.

OBESO, J. R. 1993. Does defoliation affect reproductive output in herbaceous perennials and woody plants in different ways? Functional Ecology 7:150-155.

ONUF, C. P., TEAL, J. M. \& VALIELA, I. 1977. Interactions of nutrients, plant growth and herbivory in a mangrove ecosystem. Ecology 58:514-526.

OWEN, D. F. 1978. The effect of a consumer, Phytomyza ilicis, on seasonal leaf-fall in the holly, Ilex aquifolium. Oikos 31:268-271.

OZAKI, K., KITAMURA, S., SUBIOANDORO, E. \& TAKETANI, A. 1999. Life history of Aulacaspis marina Takagi and Williams (Hom., Coccoidea), a new pest of mangrove plantations in Indonesia, and its damage to mangrove seedlings. Journal of Applied Entomology 123:281-284.

PEREBOLOTSKY, A. 1994. Tannins in Mediterranean woodland species: lack of response to browsing and thinning. Oikos 71:333-340.

PIKAKARNCHANA, T. 1981. Severe defoliation of Avicennia alba B1. by larvae of Cleroa injectaria Walker. Journal of the Science Society of Thailand 7:33-36.

RHOADES, D. F. 1979. Evolution of plant chemical defense against herbivores. Pp. 4-54 in Rosenthal, G. A. \& Janzen, D. H. (eds)., Herbivores: their interactions with secondary plant metabolites. Academic Press, New York.

ROBERTSON, A. I. 1991. Plant-animal interactions and the structure and function of mangrove forest ecosystems. Australian Journal of Ecology 16:433-443.

ROBERTSON, A. I., GIDDENS, R. \& SMITH, T. J. 1990. Seed pre- dation by insects in tropical mangrove forests: extent and effects on seed viability and the growth of seedlings. Oecologia 83:213-219.

ROCKWOOD, L. L. 1973. The effect of defoliation on seed production of six Costa Rican tree species. Ecology 54:1363-1369.

SCHIERENBECK, K. A., MACK, R. N. \& SHARITZ, R. R. 1994. Effects of herbivory on growth and biomass allocation in native and introduced species of Lonicera. Ecology 75:1661-1672.

SCHOWALTER, T. D., WEBB, J. W. \& CROSSlEY, D. A. 1981. Community structure and nutrient content of canopy arthropods in clearcut and uncut forest ecosystems. Ecology 62:1010-1019.

SCHOWAlter, T. D., HARGROVE, W. W. \& CROSSley, D. A. 1986. Herbivory in forested ecosystems. Annual Review of Entomology 31:177-196.

SCHULTZ, J. C. \& BALDWIN, I. T. 1982. Oak leaf quality declines in response to defoliation by gypsy moth larvae. Science 217:149-151.

SEASTEDT, T. R. \& CROSSLEY, D. A. 1984. The influence of arthropods in ecosystems. Bioscience 34:157-161.

SILKSTONE, B. E. 1987. The consequences of leaf damage for subsequent insect grazing on birch (Betula spp.): a field experiment. Oecologia 74:149-152.

SLANSKY, F. 1993. Nutritional ecology: the fundamental quest for nutrients. Pp. 29-91 in Stamp, N. E. \& Timonthy, M. C. (ed.). Caterpillars: ecological and evolutionary constraints on foraging. Chapman \& Hall, New York.

SMITH, T. J., CHAN, H. T., MCIVOR, C. C. \& ROBBLEE, M. B. 1989. Comparisons of seed predation in tropical tidal forests from three continents. Ecology 70:146-151.

SPRINGETT, B. P. 1978. On the ecological role of insects in Australian eucalypt forests. Australian Journal of Ecology 3:129-139.

STEVENS, J. 1999. Applied multivariate statistics for the social sciences. Lawrence Erlbaum Associates, Mahwah, NJ. 720 pp.

STONE, C. \& BACON, P. E. 1995. Influence of insect herbivory on the decline of black box (Eucalyptus largiflorens). Australian Journal of Botany 43:555-564.

STOWE, K. A., MARQUIS, R. J., HOCHWENDER, C. G. \& SIMMS, E. L. 2000. The evolutionary ecology of tolerance to consumer damage. Annual Review of Ecology and Systematics 31:565-595.

TONG, Y. F. 1998. Herbivory on the mangrove Kandelia candel (L.) Druce in Hong Kong. M.Phil. thesis, The University of Hong Kong, Hong Kong.

TRLICA, M. J. \& RITTENHOUSE, L. R. 1993. Grazing and plant performance. Ecological Applications 3:21-23.

TUOMI, J., NIEMELÄ, P., ROUSI, M., SIREN, S. \& VUORISALO, T. 1988. Induced accumulation of foliage phenols in mountain birch: branch response to defoliation? American Naturalist 132:602-608.

VAN DER MEIJDEN, E., MARIJKE, W. \& VERKAAR, H. J. 1988. Defence and regrowth, alternative plant strategies in the struggle against herbivores. Oikos 51:355-363.

WEBB, W. L. 1980. Starch content of conifers defoliated by the Douglas-fir tussock moth. Canadian Journal of Forest Research 10:535-540.

WEIS, A. E. \& BERENBAUM, M. R. 1989. Herbivorous insects and green plants. Pp. 124-162 in Abrahamson, W. G. (ed.). Plant-animal interaction. McGraw-Hill, New York. 
WHITTEN, A. J. \& DAMANIK, S. J. 1986. Mass defoliation of mangroves in Sumatra, Indonesia. Biotropica 18:176.

WOLD, E. N. \& MARQUIS, R. J. 1987. Induced defense in white oak: effects on herbivores and consequences for the plant. Ecology 18: 1356-1369.

WRATTEN, S. D., EDWARDS, P. J. \& DUNN, I. 1984. Wound- induced changes in the palatability of Betula pubescens and B. pendula. Oecologia 61:372-375.

WRATTEN, S. D., EDWARDS, P. J. \& WINDER, L. 1988. Insect herbivory in relation to dynamic changes in host plant quality. Biological Journal of the Linnean Society 35:339-350. 